\title{
Ihminen uudistuvassa työelämässä
}

Pitkänen, Pentti. 1988. Ihminen uudistuvassa työelämässä, Aikuiskasvatus 8, 1. 4-12. Marraskuussa 1987 pidettiin Joensuussa korkean poliittisen tason talouspoliittinen konferenssi Ihminen uudistuvassa työelämässä. Aikuiskoulutus nousi erääksi konferenssin keskeiseksi keskusteluteemaksi. Artikkelissa esitellään valmisteltujen puheiden poliittiset ja koulutuspoliittiset ydinajatukset ja analysoidaan niitä. Hallituspuolueiden ja työmarkkinaosapuolten puheenvuoroissa työ ja talous arvottuivat ihmistä ja koulutusta hallitseviksi ajattelun lähtökohdiksi ja perusarvoiksi. Ihmisarvon asettivat etusijalle vain opposition edustajat.

Joensuussa järjestettiin 17.11.1987 talouspoliittinen konferenssi Ihminen uudistuvassa työelämässä. Valmisteltuja puheita pitivät johtavien hallituspuolueiden ykkösministerit pääministeri Harri Holkeri ja ulkoministeri Kalevi Sorsa, oppositiopuolueiden kansanedustajat Eeva Kuuskoski-Vikatmaa ja Jarmo Wahlström sekä Toivo Yläjärvi, rahatalouden asiantuntija, Postipankin johtaja Susanna Miekk-oja, yritysten edustajat toimitusjohtajat Seppo Halttunen ja Pekka Laine sekä vuorineuvos Casimir Ehmroot ja työmarkkinaosapuolten edustajat Antero Mäki ja Jarmo Pellikka, joka keskittyi puhumaan koulutuksesta aik. opetusministeri Kaarina Suonion ohella.

Kertaan puhujien poliittiset ja koulutuspoliittiset ydinajatukset verraten tarkasti käyttäen heidän omia sanojaan, ettei ilmaisuista häviäisi arvostus, asenteellisuus eikä tunnepitoisuus. On huomattava, että puhujat edustavat alojensa poliittista ja hallinnollista, mutta eivät tieteellistä asiantuntemusta. Puheet ilmentävät esittäjiensä yleisiä arvovalintoja, joskin tilannekohtaisesti painottuneina: sanomat oli suunnattu konferenssiin kutsutuille ja niitä säätelivät konferenssi ja esitysten aiheet.

\section{Poliittiset ydinajatukset}

\section{Sorsa: Elvytyksestä uudistumiseen}

Korpilammelta Joensuuhun kokonaistuotanto kasvoi yli odotusten ja keskinäinen luottamus lujittui, mutta työttömyysaste on hälyyttävä ja henkilöstöpolitiikkaa on hoidettu huonosti: Työmarkkinaosapuolet ovat laiminlyöneet yhteistoimintalain tarjoamat mahdollisuudet. Työnantajat ovat karsastaneet hallintoedustusta ja vesittäneet työelämän uudistushankkeita. Ay-liike on laiminlyönyt jäsentensä yritystaloudellisen koulutuksen.
Suomen kansantalous on dynaamisessa kehitysvaihteessa. Tekninen kehitys avaa uusia mahdollisuuksia, ja yhteiskunnallinen asenneilmasto on yrittäjyyttä suosiva.

Edellytykset työttömyyden alentamiseen ovat hallussamme. Työllisyysongelman hoitamisessa on peräänkuulutettava paitsi yhteiskunnan myös yritysten vastuuta.

Työvoiman tarjonnan kasvu on tyrehtymässä ja työvoiman ikärakenne vanhenee. Yritysten on oivallettava kehittämisvastuunsa, uudenlainen vastuu työvoimasta ja sen kehittämisestä. Vastuuta jakamaan on saatavissa ja saatava koko yrityksen henkiset voimavarat. Henkilöstöpolitiikan asemaa yritysten päätöksentekohierarkiassa on nostettava. Henkilöstön ammattitaidon aktiivinen ylläpito ja kehittäminen kaikilla tehtävätasoilla luo tietopääomaa, jota hyödyntäen yritys voi pysyä hengästymättä kärjen tuntumassa taloudellisen kilvan maratonilla. Keinot ja menettelytavat henkilöstön kaikkien voimavarojen mobilisoimiseksi yritysten parhaaksi ovat yhteistuumin löydettävissä.

Jos tästä kokouksesta lähtisi liikkeelle uusi henkilöstöpoliittinen ajattelu, Joensuu olisi Suomen taloudelle ja yhteiskunnalle monin verroin tärkeämpi kuin Korpilampi.

\section{Miekk-oja: Rahatalouden} työympäristön muutos

Suomen talous on hyvin kehittynyt. Rahaa liikenee muuhunkin kuin välttämättömään.

Kansainvälistyminen ja säännöstelyn purkaminen mahdollistivat Suomen lyhyen rahan rahamarkkinoiden kehittämisen. Rahan hinnan määrää markkinoilla vallitseva tarjonta ja kysyntä eli markkinavoimat.

Kilpailu, ei vain kotimaisten vaan myös ulkomaisten rahoittajien kanssa on lisääntynyt. Rahaa on myytävä ei myönnettävä. Pankkien rinnalle on tullut uusiin rahoituspalveluihin erikoistuneita yrittäijiä. Arvopaperistuminen on siirtymässä Suomeen.

Panostus tietotekniikkaan, informaation nopeaan saatavuuteen ja uusien työkalujen (esim. velkara- 
hoitusvaihtoehtojen) kehittelyyn on rahoituskentässämme tärkeää tänään.

Kansainväliset rahoitusmarkkinat globalisoituvat: pääomat pääsevät nopeasti ja joustavasti siirtymään maasta toiseen hakemaan parasta tuottoa suhteessa riskiin. Suomi on osa kansainvälisiä rahoitusmarkkinoita.

Markkinavoimien hillitsemiseksi tarvitaan myös tietynasteista sääntelyä. Kotitalouksilta vaaditaan rahoitusosaamista sekä luotonannossa että sijoittamisessa. Tehokas rahoitusjohto parantaa olennaisesti yrityksen kilpailukykyä sekä koti- että ulkomailla.

Pankkien on panostettava myymiseen, tuotteenaan palvelut. On panostettava asiakkaiden tuntemukseen, kokonaistarpeiden kartoittamisen ja rahoitusratkaisujen räätälöimiseen niiden ympärille. Mutta ennen kaikkea nopeuteen.

Rahatalouden työympäristön muutos on ollut nopea ja se jatkuu. Kehitys parantaa kansantaloutemme kilpailukykyä. Tasapaino kasinotalouden ja reaalitalouden välillä on tavoittelemisen arvoinen.

Pankkitoiminnan perusarvot ovat luottamus, asiantuntemus ja palvelu ja ne säilyvät.

\section{Halttunen: Halton: PKT-yrityksen \\ synty ja kansainvälistyminen}

Ajatus oman yrityksen penustamisesta kypsyi viitisen vuotta. Rahalaitokset kuitenkin hylkäsivät pienen yrityksen kasvua ja kansainvälistymistä korostavan raha-anomuksen. Painostuksen jälkeen rahoituspäätös saatiin 1969, ja toiminta voitiin aloittaa kunnan rakentamassa vuokratilassa.

Toiminta-ajatuksena oli ryhtyä valmistamaan laitteita, joille markkinarako Suomessa oli olemassa. Yrittäjä päätti voimakkaan tuotekehityksen avulla erikoistua kapealle sektorille.

SITRA lähti 1971 rahoittamaan tuotekehittelyprojektia, minkä seurauksena yritys kehitti ja patentoi laadukkaan laitteen. Lähivientiin lähdettiin 1972. 1978 perustettiin tehdas Kanadaan: Alkuvaikeudet yllättivät, mutta yritys saatiin kannattavaksi. Kotimaan tehtaita kehitettiin jatkuvasti. Oma tuotekehitys- ja tutkimuskeskus valmistui 1984 .

Strategiaa on ollut panostaa voimakkaasti tuotekehitykseen ja valmistukseen Suomessa ja pääasiassa omien myyntiyhtiöitten kautta markkinoida tuotteita Eurooppaan ja vähäisemmässä määrin erikoistuotteita kauemmaksikin.

Suomalaisten yritysten menestyminen kansainvälisillä markkinoilla perustuu siihen, että yritysilmaston, lainsäädännön ja kustannusten suhteen voimme kilpailla tasapäisesti kilpailijamaittemme kanssa.

Suomalaisen yrityksen menestys ratkaistaan viimekädessä omalla työpaikalla. Ihmisten yritteliäisyyttä ja työntekoa tulee kannustaa. Kaikkien tulee kantaa vastuuta työpaikkansa kehittämisestä. Olemme kokeilleet henkilöstöedustajien osallistumista ryhmätyöskentelyyn, ja kokemukset ovat myönteisiä.

Yhteistyöjärjestelmien kehittämisen tavoitteena tulee olla henkilökunnan motivointi vastuun kantamiseen, viihtymiseen ja yrityksen kilpailukyvyn parantamiseen.

Yritysten vapautta hoitaa omia sisäisiä asioita tulee lisätä. Palkkauksessa tulisi kehittää tulospalkkauslinjaa. Perustutkimusta tulisi jatkuvasti kehittää. Yrityksissä tapahtuvaan tuotekehitykseen tulisi inves- toida enemmän, ja sen vuoksi pitäisi TEKESin, Keran ja Ulkomaankauppaliiton toimintaedellytyksiä parantaa.

\section{Laine: Uusia työtapoja etsimässä}

Tervakoski Oy:n ja Wärtsilä Meriteollisuuden (Wärtsilä Valmet -telakkafuusio, toimialarationalisointi) muutosprosesseissa henkilöstön vähentämistarve oli huomattava. Henkilöstön uudelleen työllistymistä valmisteltiin monin keinoin: Tervakoskella perustettiin työnvälityspiste yritykseen, käynnistettiin yrittäjäkoulutusta, hankittiin erityisalue-etuudet ja luotiin korvaavia työpaikkoja perustamalla teollisuushalleja rakennuttanut osakeyhtiö. Uudelleen työllistymistä edisti ihmisten vapaaehtoinen hakeutuminen muihin työpaikkoihin. Uudelleen koulutus ei houkutellut.

Yhteistyötä henkilöstön kanssa ei aluksi saatu kunnolla käyntiin. Yhteistyö eri viranomaisten kanssa Tervakoskella oli epävirallista. Telakkayhtiötä muodostettaessa yhteistyö virallistettiin.

Muutosprosessin vaiheet yrityksessä: On luotava visio yrityksen menestymismahdollisuuksista ja strategia kannattavaan toimintaan; On selvitettävä muutoksen vaikutukset henkilöstöön ja yrityksen tai toimintapaikkakuntien talouteen ja työllisyyteen; On käynnistettävä oppimisprosesseja organisaatiossa toiminnan uudelleen suuntaamiseksi; Tavoitteet tulee purkaa avaintehtäviksi vastuualueittain niin että organisaation kaikilla tasoilla (koko henkilöstön asiantuntemus huomioon ottaen) pystytään selkiyttämään se, millaisin toimenpitein menestys on saavutettavissa. Johdon tulee aktiivisesti osallistua keskusteluihin henkilöstön kanssa ja tiedotustoiminnan tulee olla selkeätä ja tosiasiapohjaista oman henkilöstön, asiakkaiden, osakkaiden ja rahoittajien luottamuksen säilyttämiseksi.

Työikäinen ja -kykyinen väestö tulee pitää työelämän piirissä aktiivisen työhön sijoittamisen ja uudelleen kouluttamisen avulla. Ennenaikaiseen eläkkeelle siirtämisen järjestelmiä ei tule rakentaa. Työttömyysajan alkuun toimeentuloturvaksi luotu eroraha-järjestelmä ei edistä työttömäksi jääneiden nopeaa työllistymistä. Se tulisi liittää koulutukseen tai uuden työpaikan hakemiseen. Työvoiman liikkuvuuden tukimuotoja (asuntotuotanto) olisi kehitettävä. Viranomaisten vastuunjaosta rakennemuutostilanteissa pitäisi tehdä päätös.

Rakennemuutostilanteessa on myös yrityksen osallistuttava ja avustettava ratkaisuvaihtoehtojen hakemisessa työtä vaille jääville. Jotta muutosten toteuttaminen onnistuisi, tulee yrityksen johdon, esimiesten ja henkilöstön aidon yhteistyön perustua motivoituneen henkilöstön varauksettomaan haluun tukea yrityksen menestymistä. Hallintoedustus on vain edustuksellinen osa yhteistoimintaa.

Kansantalouden kannalta on tärkeää, että muutosprosessien toteuttamista pyritään edistämään ja luomaan toimintamalleja, joilla helpotetaan ihmisten mahdollisuuksia siirtyä tehtävästä tai ammatista toiseen.

Päättäjien on kehitettävä visioita tulevaisuuden teollisuuspolitiikasta. Voimavaroja tulisi ohjata valittujen alojen perustutkimukseen sekä korkeakoulutukseen ja ammattikoulutuksen uudelleen suuntautumiseen. Vastaavasti tulisi pystyä ennakoimaan ongelma-aloja ja tehtävä ratkaisuja oikeaan aikaan lykkäämättä niitä epämääräiseen tulevaisuuteen. 


\section{Yläjärvi: Maaseutu muuttuu, miten?}

Maataloustuotannon tulee laskea lähemmäksi Suomen omaa elintarvikekulutusta. Tavoite voi toteutua nopeastikin: Maatalouden rakennemuutos toteutuu työvoiman ikääntymisen ja eläkkeelle jäännin kautta. Viljelijöistä $43 \%$ on 55 vuotta täyttäneitä. Viljelystä luopuvien toimeentulo on kohtuullinen nykyisten eläkejärjestelyjen jälkeen. Tilakohtaiset tuotannonrajoitukset jäädyttävät tuottavuuden nousun ja estävät tuotantovälineiden tehokkaan käytön.

Työllisen työvoiman osuus 1985 oli maataloudessa $7,8 \%$ ja metsätaloudessa 2,4\%. Metsätalouden osuus pysynee ennallaan. Sen sijaan maatalouden työvoima vähenee: sen työvoimaosuus olisi $5 \%$ vuonna 2000. Koko muutos kohdistuu maaseudulle, jonka osuus on noin $25 \%$ Suomen työvoimasta. Maaseutu keskimäärin kokisi melkomoisen muutoksen. Muutoksen rajuus korostuu alueilla, joilla alkutuotannon työvoimaosuus voi olla 60-70 \%; niiden työpaikkojen väheneminen olisi 25-30 \%. Tällaisten alueiden ongelmien hoitoon yhteiskunta ei ole varautunut.

Maaseudun kehittämiseksi: 1) Nuorten viljelijöiden tilojen tuottavuuden kehitys on turvattava kestävällä tavalla; 2) Metsätalouden panostuksen ja tulojen aikaero-ongelma on ratkaistava. 3) Maaseudun elinkeinojen rahoitus vaatii nopeaa muutosta. 4) Työpaikkojen muutostarve alkutuotannosta yksityisiin palveluihin vaatii asennemuutosta. 5) Tulevaisuuden maatalouden rakenne on hahmotettava.

Maatalouspolitiikan seurausvaikutukset kohdistuvat ensisijaisesti maaseudun rakenteeseen, maataloustuotantoa palvelevaan teollisuuteen sekä elintarviketeollisuuteen.

On erikseen kiireellisesti selvitettävä maatalouden tuotannon ja rakenteen alueellista kehitystä ja siihen liittyviä yhteiskunnallisia ongelmia.

\section{Kuuskoski-Vikatmaa: Yksilö, yhteistyö ja julkinen sektori}

Tasa-arvo? Vaadimme itsellemme lisäetuuksia. Huono-osaisille (työttömät, vammaiset) riittäköön välttämättömin. Emme enää pyri tasa-arvoon.

Ihmisen eheys? Eheyden ydin on siinä, että ihminen voi luoda omat arvonsa ja asettaa oman elämänsä päämäärät. Sekä aineellisen hyvinvoinnin että henkisen tasapainon parantamiseksi toimitaan silti ikään kuin ihmisen elämän päämääränä olisi kilpailukyky tuotantoelämässä. Saako teknisteollinen kilpailutalous pirstoa jatkossakin ihmisen eheyden?

Yhteisvastuu? Ajatellaan, että vastuu kuuluu yhteiskunnalle organisaatioineen, ei minulle. Vuorovaik utusta toisiin ihmisiin ei kuitenkaan voida korvata millään organisaatiolla eikä lähimmäissuhteita ja inhimillistä kanssakäymistä voida määrätä lainsäädännöllä. Milloin olemme valmiit tunnustamaan, että työ, josta nyt ei makseta palkkaa, on yhteiskunnankin kannalta arvokasta.

Itsekkyys? Hyvinvoiva enemmistö tulee yhä itsekkäämmäksi. Vaaditaan, että on puhuttava enemmistöjen puolesta, vähätellään kuuden prosentin työttömyyttä ja korostetaan sosiaaliturvamme olevan maailman kattavimpia. Onko itsekkyys ylittänyt sen rajan, ettemme kykene näkemään ympärillämme olevia epäkohtia (työttömyys, perusturvan puutteet, epätoivo, väkivalta, rikollisuus).
Tulosvastuu? Ihmisten ja perheiden elämässä on tilanteita, joissa tarvitaan ammatti-ihmisen apua. Olemme rakentaneet kattavan ja monipuolisen palveluverkoston, josta valtio ja kunnat yhdessä vastaavat. Palvelujärjestelmien toimivuutta ei kuitenkaan voida mitata sillä, kuinka monta suoritetta niissä saadaan päivässä aikaan tai mikä on suoritusten hinta. Ainoa oikea mittari on, miten ne palvelevat kansalaisia ja miten ne vastaavat inhimilliseen hätään.

Julkisten palvelujen inhimillisyys? Byro-organisaatioissa työn tärkein sisältö, lähimmäisen auttaminen ja hoitaminen, on hukkumassa. Hoidon ja palvelun korkea eettinen taso vaatii aina henkilökohtaista vastuunottoa ja sitoutumista tehtävään. Inhimillisesti korkeaa palvelutasoa ei saada aikaan kannustuslisillä ja urakkapalkoilla, kuristavilla suoritevaatimuksilla ja ahdistavilla määräyksillä.

\section{Wahlström: Voidaanko rakennemuutosruhjeet ehkäistä?}

On hämäystä väittää meneillään oleva ns. hallitun rakennemuutoksen yhteisymmärryspolitiikka yhteiseksi, demokraattisesti tehdyksi valinnaksi. Ensimmäinen ehto on valintojen poliittisuuden tunnustaminen, toinen on valinnoista keskustelu ja kolmas niistä päättäminen poliittisissa päätöksentekoelimissä. Myös talouspolitiikasta pitää keskustella ja päättää eduskunnassa.

Puhuminen yhteisymmärryksestä on asioiden poliittisuuden, valinnan mahdollisuuden kieltämistä, yritys saada kaikki yhteiskunnalliset voimat ainoaksi väitetyn vaihtoehdon taakse. Konsensus on käsitetty niin, että ongelmia ovat ne asiat, jotka yksimielisesti on ongelmiksi todettu. Vain niihin etsitään ratkaisua. Muut ongelmat lakaistaan suuren konsensusmaton alle! Kun on täysin vastakkaisia käsityksiä työttömyydestä, työsuhdeturvasta, asuntopolitiikasta tai perustoimeentulosta, niitä ei hoideta lainkaan.

Keskiarvoajattelu, yhteiskunnan sosiaalisen vastuun kiertäminen ja palkkatyöhön sidottu ajattelu kärjistävät toimeentulo-ongelmia. Koko systeemi, kilpailu, korostaa itsekkyyttä ja vastuuta vain omasta elämästä. Muiden osattomuus ei kosketa. Kulutus on ns. hyvinvointivaltion elämänsisältö. On vaarana, että työelämän ulkopuolella olevia: opiskelijoita, työttömiä, sairaita, lapsia tai eläkeläisiä aletaan pitää painolastina. Ihmisiksi näillä ryhmillä on liian vähän kulutuskykyä!

On valittu työttömyys. On valittu kansainvälistymiseen sopeutumisen politiikka? Entäpä, jos sopeutumisen sijasta päättäisimme asettaa ihmisen ja ympäristön keskeisimmäksi, ja siitä lähtökohdasta tekisimme valintamme?

Politiikan päätehtävänä tulisi olla oikeudenmukaisuuden ja tasa-arvon puolustaminen sekä kansalaisten vaikutusmahdollisuuksien lisääminen. Talouspolitiikka, joka syjäyttää nämä tavoitteet, ei ole välttämätöntä, vaan väärää. Yhä vaikeammalta näyttää saavuttaa tulonjaon oikeudenmukaisuus, vaikka Suomessa on rikkautta enemmän kuin koskaan.

On valittava sosiaalinen yhteiskuntapolitiikka tavoiteena valtio, jossa vähäosaisten asema paranee nopeammin kuin muualla, jossa tuloerot supistuvat, ympäristö säilyy terveenä, demokratia laajenee työelämässä ja vastuuta kannetaan koko maailmasta. Tämäkin vaihtoehto vaatii panostusta koulutukseen, 
teknologian kehittämistä, aktiivista paikkamme etsintää kansainvälisessä työnjaossa ja yhteistyötä oman maamme asioissa.

\section{Mäki: Palkansaajat työelämän muutoksissa}

Moni työntekijä ei tänä päivänä välitä työstään. Useiden ihmisten työ on yksitoikkoista, raskasta, henkisesti tylsistyttävää, vaikutusmahdollisuuksista puhdistettua ja suhteellisen huonosti palkattua.

Ihmisten työhalujen ylläpitämiseksi tarvitaan uusia keinoja. Työmotivaatiota ja uskoa työnteon mielekkyyteen voidaan lisätä työntekijöiden vaikutusmahdollisuuksia kasvattamalla (mm. työntekijöiden hallintoedustuksen järjestäminen ja yhteistoimintamenettelyn kehittäminen). Kysymys on työtyytyväisyyden lisäksi henkilöstön voimavarojen hyödyntämisestä tuotantoa ja palvelua kehitettäessä. Henkilöstön osallistumismahdollisuuksia lisättäessä on kuitenkin varottava yksioikoisia tulospalkkamalleja, joissa investointi- ja työllisyysnäkökohdille ei anneta riittävää painoa.

Työntekijäpuoli haluaa lisäksi yritysten toimintaa säädeltäväksi sopimusten ja lakien avulla. Työelämän uudistamisen tärkein asia on erityisesti työsopimussuhteessa työskentelevien työsuhdeturvan parantaminen irtisanomisia ja lomautuksia vastaan. Lainsäädäntöä pitäisi muuttaa niin, että yritykselle asetettaisiin ensisijaisesti henkilöstönsä uudelleenkouluttamisen ja -sijoittamisen velvoite. Yhteistoimintalaki on saatava sellaiseksi, että yrityksissä haetaan todellisia vaihtoehtoja lomautuksille ja irtisanomisille ja että työntekijöiden vaikutusmahdollisuuksia lisätään.

Yhteistoiminta on laajennettava koskemaan myös konserneja ja monitoimipaikkayrityksiä. Yrityskaupat, fuusiot ja uuden tekniikan käyttöönotto ovat kaikki yhteistoimintamenettelyyn kuuluvia ja sopivia asioita.

Lait ja sopimukset asettavat yritysten kehittämiselle reunaehtoja. Jos työntekijät näiden ansiosta kokevat asemansa turvatuksi ja kokevat saavansa osansa tuotannon tuloksista, niin he mitä todennäköisimmin osallistuvat mielellään myös yrityksen ja tuotannon kehittämiseen. Yritysten pitää voida kehittyä, mutta ei jauhamalla väkeä tehtaiden portista sisää ja ulos.

Työnantajat ovat uudistuksessa avainasemassa: he voivat toteuttaa sellaisiakin uudistuksia, joihin ei mikään pakota - ja toisaalta vaikeuttaa muita uudistuspyrkimyksiä. Todetaanhan sopimuksissa, että työnjohto-oikeus kuuluu työnantajalle.

Ammattiyhdistysliike pyrkii työelämän nykyaikaistamiseen neuvotteluteitse. Työnvälityksen huono toiminta lisää tarpeettomasti työttömyyttä ja rakennemuutosongelmia.

\section{Ehrnroot: Henkilöstö yrityksen voimatekijänä}

Yritystoiminnassa menestyminen edellyttää yritykseltä oman liiketoimintansa hyvää osaamista, keskittymistä toiminnassa siihen, mitä osaa, yrityksen kehitysvaiheeseen sopivaa parhainta mahdollista teknologiaa ja tuotantokoneistoa sekä ammattitaidollisesti pätevää, tehokkaasti työskentelevää henkilökuntaa, joka viihtyy työssään ja kokee sen mielenkiintoiseksi. Kun lisäksi työntekijän suhde esimie- hiinsä on kunnossa ja työpaikka myöskin pitkällä tähtäyksellä turvallinen sekä mahdollisuudet edetä uralla kohtuulliset, voidaan puhua kokonaisuudesta, joka on yritykselle suuri voimavara.

Hyvä yritys ottaa palvelukseensa hyvin koulutettuja, ammattitaitoisia ja vireitä ihmisiä. Kysymys onkin enemän siitä, miten hyvä henkilökunta saadaan pidetyksi yrityksen palveluksessa ja miten nämä henkilöt saadaan motivoitua työskentelemään yrityksen tavoitteiden suuntaisesti. On myös osattava pitää huolta siitä, että henkilökunnan pyrkimys ylläpitää ja kehittää ammattitaitoaan säilyy ja että halukkaille järjestetään siihen mahdollisuus.

Avainasia on se, että yrityksen henkilökunta saadaan ymmärtämään yhtiön tavoitteet ja myötävaikuttamaan yrityksen toimintaan tavalla, jolla heidän osaamisensa voidaan parhaiten yhtiön ja koko työyhteisön hyväksi hyödyntää. Tähän ei ole mahdollista päästä ilman luottamukseen ja tehokkaaseen tiedonvälitykseen perustuvaa suhdetta johdon ja henkilöstön kesken.

Päätösvaltaa on yrityksessä pyrittävä viemään niin lähelle varsinaista toimintaa kuin suinkin mahdollista. Sen varmistaminen ja henkilöstön myötävaikutuksen järjestäminen on paitsi yhtiön etu myös tärkeä motivaatiotekijä henkilökunnalle. Työn antaman henkisen tyydytyksen ohella tärkeä motivoiva tekijä on palkkaus, johon voidaan liittää saavutetusta tuloksesta riippuvia kannustimia. Tuotantopalkkiot antavat lisäansiota tuotannon määrän noustessa. Ne eivät ehkä kuitenkaan ota riittävässä määrin huomioon aikaansaadun tuotannon taloudellista tulosta. Osa lisäyksestä, joka yhtiön tulokseen on aikaansaatu yhtiön johdon ja henkilöstön hyvän yhteistyön tulokseen, voitaisiin siirtää henkilöstön hyväksi yhtiön henkilöstön hallitsemalle rahastolle.

Mikäli henkilöstön myötävaikuttamisen (henkilöstökoulutus) ja erilaisten kannustinjärjestelmien (rahastot) kautta halutaan luoda edellytyksiä paremmalle tulevaisuudelle yrityksissä, on kullekin yritykselle sopivat järjestelmät kehitettävä itse yrityksessä. Valtiovallan tulee järjestää tarvittaessa puitteet, jotka mahdollistavat monipuoliset yrityskohtaiset järjestelyt, ja avata lainsäädännöllisiä kapeikkoja, jotka estävät yrityksiä toteuttamasta tarpeelliseksi havaitsemiaan toimenpiteitä organisaationsa ja johtamisensa kehittämisessä.

\section{Holkeri: Yhteisymmäryspolitiikan syventäminen}

Tulevaisuutemme on paljolti omissa käsissämme, jos niin yhdessä tahdomme ja päätämme. Suomi ei ole taloudellinen ajopuu. Virtaa emme kuitenkaan voi kääntää.

Yhteisymmärryksen syventäminen tarkoittaa yhteisen edun tajuamista ja rajojen asettamista eri mielipiteiden keskinäiselle kamppailulle. Eri tahtoihin sisältyviä voimalatauksia on käytettävä yhteiseksi hyväksi.

Pienen maan parhaita menestyskeinoja avoimen talouden olosuhteissa on hyvin toimiva sisäinen yhteistyö. Opittua talouspolitiikan hoitotaitoa tulee sekä vaalia että kehittää. Yhteistyökeinoja tarvitaan ennakoivaan edunvalvontaan kasvavassa kansainvälisessä yhteistyössä. Kansallisen kulttuuripohjan vahvistaminen on yhteistyöponnistuksia vaativa työ- 
kenttä. Julkisen ja yksityisen sektorin välille tarvitaan uutta yhteistyöhenkeä: Myös hallituksen ja yleensä julkisen vallan on pysyttävä tahdissa mukana ja uudistuttava tavalla, joka tuntee vastuunsa tulevaisuudesta, ei holhoa, vaan pitää huolta, luottaa ja antaa vastuuta, muttei jätä heitteille.

Hallituksen näkökulmasta keskeisimmät yhteistyötä vaativat alueet ovat hallitusohjelmassa kirjatut asiat: työllisyyden hoidosta ja alueellisesta kehityksestä huolehtiminen, työelämän uudistus ja verouudistus. Uudenaikaisen hyvinvointivaltion roolin tulisi kehittyä joustavan yhteistyövaltion suuntaan. Valtion osaksi tulee ja sille tarjotaan jatkuvasti uusia tehtäviä. Niitä ottaessaan valtion tulisi olla hyvin käytännönläheinen ja joustava. Kansalaisten, yritysten ja järjestöjen omaehtoinen toiminta ja yhteistyö on asetettava etusijalle. Tilanteen ja yhteisen edun vaatiessa valtion tulee kuitenkin puuttua voimakkaastikin epäkohtiin ja ottaa aloite asioiden hoidossa käsiinsä. Hallituksen rooliin kuuluu taito toimia aikaisempaa nopeammin, mutta vastaavasti kyky myös vetäytyä tehtävistä, kun asiat alkavat muuten hoitautua.

On aika siirtyä hallintokulttuurista palvelukulttuuriin.

Uuden yhteisymmärryspolitiikan avainsanoja ovat koulutus, nopeus ja joustavuus.

Hallituspuolueiden edustajien näkemykset eroavat olennaisesti opposition näkemyksistä. Holkerin ajatusmaailmassa korostuvat kansallinen yhteisymmärrys ja kansainvälinen kilpailukyky. Kansallista yhteisymmärrystä tulee syventää erityisesti kansainvälisen kilpailukyvyn ja suomalaisten hyvinvoinnin kohentamiseksi tavoitteina esim. "hyvinvointivaltioiden paras verojärjestelmä" ja 1990-luvulla "maailman paras koulutuspolitiikka". Kun perusarvona on kansallinen hyvinvointi, ei ajattelun lähtökohdaksi sovellu kansainvälistä solidaarisuutta vaativa ihmisyys. Holkeri elää lähitulevaisuudessa ja tulevaisuudessa (1990-luvulla) ja uskoo hallituksen kykenevän nopeisiin, mutta kestäviin ratkaisuihin hallitusohjelmaan valittujen asioiden hoitamisessa. Pyrkimyksestä nopeisiin ratkaisuihin seuraa, ettei demokraattiselle keskustelulle koeta jäävän riittävästi aikaa. Siitä seuraa myös, että kestävien ratkaisujen sijasta on tyydyttävä etenemään vähin askelin. Holkerille luonteenomaista on halu tarkastella asioita myönteisessä valossa. Holkeri puhuu esim. työllisyyden hoidosta, ei työttömyydestä.

Sorsa esiintyy Joensuussa yritysten edustajille. Myös Sorsa painottaa taloudellisen kilpailukyvyn merkitystä ja toteaa, että yritysten koko henkilökunta on saatava toimimaan yrityksen parhaaksi. Sorsan sosialismi ilmenee siten, että tavoitteena on henkilöstöpolitiikan asemaa yrityksissä kohentamalla saattaa henkilökunta osallistumaan yritystalouden hoitoon. Sorsan- kin esitystä hallitsee työn arvostus yli ihmisyyden arvostuksen. Ihmistä lähestyessään Sorsa puhuu työvoimasta, henkilöstöpolitiikasta ja yritysten henkilöstöstä.

Oppositio on oivaltanut hallituksen linjavalinnat yksipuolisiksi ja esittää politiikkansa lähtökohdaksi ihmisarvosta kumpuavan vaihtoehdon. Kuuskoski-Vikatmaa epäilee tasa-arvon ja yhteisvastuun unohtuneen, kilpailutalouden pirstovan ihmisen eheyden, hyvinvoinnin lisäävän enemmistön itsekkyyttä, tulosvastuun johtavan järjettömyyksiin ja työn tärkeimmän sisällön, lähimmäisen auttamisen ja hoitamisen, hukkuvan palvelualoilla. Kuuskoski ihannoi ihmisen sitoutumista työhön, mutta haluaisi laajentaa työn käsitettä sisällyttämällä siihen sellaistakin työtä, josta nyt ei makseta palkkaa.

Walström asettaa ihmisen ja ympäristön keskeisimmäksi politiikan lähtökohdaksi kansainvälistymiseen sopeutumisen sijasta. Hän korostaa, että politiikasta ja talouspolitiikasta pitää keskustella ja päättää eduskunnassa, ja puhuu sosiaalisen yhteiskuntapolitiikan puolesta. Wahlström pitää puhetta yhteisymmärryspolitiikasta hämäyksenä.

Holkeri sanoi yhteisymmärryksen syventämisen tarkoittavan yhteisen edun tajuamista ja rajojen asettamista eri mielipiteiden keskinäiselle kamppailulle. On ilmeistä, että Holkerin rajaus sisältää ensisijaisesti pyrkimyksen yhteisymmärryksen tavoittamiseen hallituspuolueiden kesken, mikä jo saattaa osoittautua oletettua vaikeammaksi. Mikäli Holkerin korostaman kansallisen yhteisymmärryksen saavuttaminen on hallituksen päämääränä, sen tulee ei vain kuulla opposition ääntä seminaarissa, vaan syventää opposition ymmärtämystään ja muuntaa sisäpolitiikkaansa. Ellei oppositio tähän taivu, saattaa Koivisto-Holkeri linja merkittävissä kysymyksissä murentua kapeuteensa. Missään tapauksessa Holkerin puhetta ei voida tulkita siten, että yhteisymmärryksen piiri oli maailmanlaajuinen.

Miekk-oja kuvaa rahatalouden työympäristön nopeaa muutosta, kansainvälistymistä, liberaalistumista, teknistymistä ja monipuolistumista. Ihmiset ja yritykset sijoittavat yhä enemmän aikaansa raha- ja arvopaperityöhön eli kuluttavat aikaansa kasinopeleihin. Näin rakennetaan reaalituotannon ohella kansallista hyvinvointia.

Yritysten ja työmarkkinaosapuolten edustajat (Halttunen, Laine, Ehmroot, Mäki, Pellikka) korostavat yksimielisesti työn arvoa ja haluavat motivoida ihmisiä tekemään työtä ja kehittämään yritystä kaikin voimin. Näkemykset keinoistakin ovat pääosin yhdensuuntaisia ja työn yliarvostuksen puitteissa liberaaleja. 


\section{Koulutuspoliittisia ydinajatuksia}

Yläjärveä lukuunottamatta kaikki puhujat sivusivat tai koskettelivat koulutusta, jota pidetään rakennemuutoksen hallitsemisen keskeisenä keinona. Sen lisäksi mitä edellä Sorsa, Laine, Wahlström, Mäki, Ehrnroot ja Holkeri ovat yleisemmässä yhteydessä puhuneet koulutuksesta, ovat puhujat kajonneet siihen seuraavasti.

\section{Sorsa:}

Pienellä kansakunnalla ei ole varaa tuhlata henkilöstöresurssejaan. Kasvua on vain vanhemmissa ikäryhmissä, joihin suuret ikäluokat - heikosti koulutettuina ja syräytymisen, uloslyönnin uhka päällänsä - ovat nyt siirtymässä. Uutta ammattitaitoa ja osaamista ei enää opetussektorin toimittamana virtaa yrityksiin entisessä mitassa. Yritysten on nyt itse oivallettava vastuunsa ja koulutettava jatkuvasti työvoimaansa.

\section{Miekk-oja:}

Kansainvälisten pankkien kannattavuus on heikentynyt, työntekijöitä on irtisanottu ja palkkoja pienennetty. Kokemus ja koulutus ovat tulleet arvoon. Kehitykseen sopeutumisen avainsana on koulutus ja tieto. Uusien tehtävien vaatima uudelleenkoulutus pankeissa on aloitettu. Suomessa pankkitoimihenkilöiden pohjakoulutus on korkea. Kouluttajien haasteena onkin osaavan henkilökunnan motivoiminen, asenteiden muuttaminen sekä tietyn mystisyyden poistaminen uusien tuotteiden ja uuden tekniikan ympäriltä. Koulutuksen, jonka tulisi tapahtua lähellä operatiivista toimintaa, suurin ongelma on kouluttajien puute. Ne harvat, joille uusi toiminta on tuttua, ovat kiinni operatiivisessa työssä.

Koulutus tulisi suunnata myös asiakkaisiin. Toivoisin, että sekä koululaitos että korkeakoulut panostaisivat enemmän nykyaikaiseen raha- ja pääomamarkkinatietouden koulutukseen.

\section{Halttunen:}

Oli rakennettava vieraalle kulttuurialueelle (Kanada) tehdas, koulutettava henkilökunta ja löydettävä asiakkaat.

Uskon työn tuottavuuden kohoavan taloudellisen aikuiskoulutuksen, asennemuokkauksen ja paremman kaksisuuntaisen tiedonkulun avulla.

Työvoiman liikkuvuus ja ammattiryhmästä toiseen siirtyminen tulisi tehdä ihmiselle houkuttelevaksi ja koulutusta tulisi edelleen kehittää.

\section{Laine:}

Ongelmaksi osoittautui, että uudelleenkoulutus ei houkutellut: Kun työllisyyskoulutuksesta maksettava korvaus on saman suuruinen kuin työttömyyskorvaus, miksi mennä kurssille, kun saman rahan saa muutenkin. Uskon, että yritykset olisivat tällaisissa tilanteissa valmiita maksamaan palkan ja työttömyyskorvauksen erotuksen, jotta koulutus koettaisiin houkuttelevaksi vaihtoehdoksi. Tämä edellyttää kuitenkin säännösten muuttamista.

Telakalle perustetun työnvälitysyksikön tarjoamia palveluja ei täysimääräisesti hyödynnetty. Muun muassa koulutustarpeen kartoitusta ei päästy tekemään. Valtiovallan ja työmarkkinaosapuolten tuella tulisi kehittää työnvälityksen palvelutasoa ja siten parantaa myös uudelleenkoulutuksen arvostusta.

\section{Mäki:}

Työelämän muuttuessa koulutuksen merkitys yleensä ja erityisesti yritysten sisäisen koulutuksen merkitys korostuu. Kansakunta ja kansalaiset on muutettu yritysten palvelijoiksi, mikäli yritykset rakennemuutoksessa heittävät vanhat ja kouluttamatta jättämänsä työntekijät ulos ja ottavat uuden satsin yhteiskunnan sopivasti kouluttamia tilalle. Oman väen ammattitaidon puutteita eli jatko- ja täydennyskoulutuksen laiminlyöntiä käytetään usein myös verukkeena siirrettäessä yrityksessä tehtyjä töitä ulkopuolisille alihankkijoille.

Kannatan kolutusrahastotyyppistä jänjestelyä rakennemuutoksista aiheutuvan koulutustarpeen hoitamiseksi. Myös suhdannesyistä aiheutuvia tuotantoseisokkeja voitaisiin rahastoinnin avulla käyttää hyödyksi työntekijöiden kouluttamiseen yritysten maksukykyä vaarantamatta. Rahastojärjestely voitaisiin hoitaa esimerkiksi Erorahaston tehtäväaluetta laajentamalla.

Koulutus ei liity vain rakennemuutokseen sopeutumiseen. Koulutuksen tulee edetä myös rinnan työntekijöiden osallistumisen lisääntymisen kanssa, jotta me todella osaisimme käyttää yhteiseksi hyödyksi tulevaisuuden mahdollisuudet.

\section{Holkeri:}

Työllisyyden hoito ja työelämän uudistus ovat myös sidoksissa toinen toisiinsa. Yhdistävä lenkki on koulutuksessa.

1990-luvun yhteiskuntapoliittiseksi ykkösongelmaksi on osoittautunut koulutus. Aloittakaamme yhteisymmärryspolitiikan syventäminen koulutuksesta.

Koulutus kuuluu valtionhallinnossa opetusministeriön toimialaan, mutta se koskee useita ministeriöitä. Meillä on neuvostoja ja muita elimiä miettimässä koulutuksen eri osien tavoitteita. Nyt olisi kuitenkin viisaiden tehtävänä kiireesti laatia ehdotus koko väestön elinikäiseen koulutusjänjestelmään siirtymisestä. Tervehtisin tyytyväisenä ehdotusta, joka ottaisi huomioon elinkeinoelämän, työllisyyden, aluepolitiikan, kansainvälistymisen ja kulttuurin näkökohdat. Toiveeni olisi, että tämän työn ensimmäiset suuntaviivat olisivat käytettävissä, kun budjettiesitys vuodelle 1989 lyödään lukkoon.

\section{Suonio: Koulukin voi kasvattaa muutokseen}

Meillä on hyvä koululaitos (yhdeksän vuoden yleissivistävä koulutus; koko ikäluokalle ammatillisesti eriytyvä koulutus; tiheä kouluverkko; ammattitaitoinen, hyvin koulutettu opettajakunta jne.). Aikuiskoulutuksella on pitkät perinteet yleissivistävässä koulutuksessa, kolmen vuosikymmenen kokemus työllisyyskoulutuksessa ja nyt se on laajenemassa kaikkiin ammatillisiin oppilaitoksiin uuden lainsäädännön myötä.

On kuitenkin tärkeämpää tarkastella koulutuksen sisältöä kuin ulkoisia rakennuspuita. Kouluamme syytetään irtotiedon kasaamisesta ja oppiaineiden 
pirstalemaisuudesta. Paljon tärkeämpää on oppia hankkimaan tietoa kulloinkin esille tulevaan ongelmaan, jäsentàmààn tietoa, tuottamaan tietoa ja käyttämään sitä luovasti. Tärkeintä olisi herättää aito kiinnostus asioihin ja ilmiöihin.

Säilyttävä oppiminen on välttämätöntä jokaisen yhteiskunnan toiminnalle ja vakavuudelle. Mutta "toinen oppimismuoto", uudistuva, innovatiivinen oppiminen on vielä tärkeämpi. Se voi aiheuttaa muutosta, uudistuksia, ongelmien muotoilua uudelleen ja uudelleenasettelua. (Oppimisen uudet haasteet, 1979).

Monessa suomalaisessa yrityksessä harrastetaan luovuuskoulutusta. Näin syntyy yhteisöön kulttuuri, jossa ideointi, asioiden katsominen uudella tavalla, on herkässä. Vaikka vain kourallinen sadoista oivalluksista johtaisi vakavaan kehittelyyn ja niistä vain osa toteutukseen, ollaan edellä - ollaan tulevaisuudessa.

Oppimista voidaan uudistaa. Suomalaisessa koulussa on opettajilla täysi pedagoginen ja didaktinen vapaus. Opettaja voi valita ja kehittää menetelmäänsä. Oppiminen voi olla innostavaa, luovaa, ongelmakeskeistä, osallistuvaa ja siis uudistavaa oppimista. Vaikeaa oppimisen uudistaminen on siksi, että on paljon kahleita, joita pitäisi jaksaa murtaa (oppikirjojen orjuutus; opetussuunnitelmien ja oppimismäärätavoitteiden sokea noudattaminen; suoritusten mittaaminen; oppilaiden keskinäisen kilpailun käyttö; oppiaineiden erillisyys; harha, jonka mukaan vain taideaineilla on luovuutta kirvoittava sisältö ja tehtävä; oheiskasvattajien turmiollinen vaikutus).

Mitä tekemistä uudistavalla oppimisella ja uudistuvalla työelämällä on keskenään? Voidakseen hallita elämäänsä ja vaikuttaa tulevaisuuteen niin työelämässä kuin muissa toimissaan ihmisellä tulee olla valmiudet kohdata muutos luovasti. Tähän liittyy myös valmıus jatkuvaan itsensä kehittämiseen. Uudistuva työelämä puolestaan tarvitsee monipuolisia, luovia, aloitteellisia ja itseään arvostavia ihmisiä.

Työelämä vastusti aikoinaan ammatillisen koulutuksen laaja-alaistamista, yleissivistävien aineiden sisällyttämistä ammatilliseen koulutukseen ja koulutusaikojen pidentämistä. Pitkäjännitteinen tulevaisuuteen kurottaminen ei vieläkään tunnu olevan yritystoiminnassa yleisenä viisautena. Jos niin olisi: Yritykset toimisivat kiinteässä vuorovaikutuksessa oppilaitosten kanssa (työelämään tutustuttaminen; kesätyö; koulutus- ja oppisopimukset; yritysten parhaat asiantuntijat oppilaitosten neuvottelukuntiin ja tuntiopettajiksi); Yritykset käyttäisivät hyväkseen työntekijöiden koulutusta ja työssä karttunutta kokemusta laajentamalla osallistumista päätöksenteossa; Yritykset huolehtisivat jatkuvasti ja tulevaisuutta ennakoiden henkilöstönsä jatko- ja täydennyskoulutuksesta.

Suomalaisella koulutusjärjestelmällä on vahva pohja ja toimiva rakenne, joka pitää hienosäätää, mutta ei jälleen mullistaa. Koulun uudistamisessa olisi nyt keskityttävä sisältöön. Koulu voi ja sen tulee kasvattaa tulevaisuuteen. Tulevaisuuteen valmistautumisen ja muutoksen hallinnan tulisi ohjata koulun työtapoja, ilmapiiriä, pedagogisia valintoja, jokaisen opettajan ja oppilaan yhteistä oivallusta.

\section{Pellikka: Palvelualojen koulutusmalli}

Nuorisoasteen peruskoulutus on kehittynyt viime vuosına myönteiseen suuntaan. Aikuisten ammatillinen koulutus on sitävastoin retuperällä. Lähivuosina on kehıttämisen painopiste siirrettävä selvästi tähän koulutusmuotoon. Työelämän nopea muutos vaatiı alkussten ammattitaidon jatkuvaa kohentamista.

Ehdotan aikuiskoulutusmallia, jossa työssä olevien ammatillinen koulutus kytketään tiiviisti työ- ja vapaa-aıkaan. Koulutus-työ-koulutus-työ ... on jatkuvaa oppimista. Opiskelujaksot nivoutuvat työntekoon ja vapaa-aıkaan. Työntekijän itsensä on ensisijaisesti vastattava siitä, että tiedot ja taidot pysyvät ajan tasalla. Myös yrityksen ja yhteiskunnan vastuu korostuu tulevaisuudessa entistä enemmän.

Ammatillisen jatko- ja uudelleenkoulutuksen tulee perustua todettuun tarpeeseen sekä yrityksen että työntekijän näkökulmasta. Koulutuksen tuotoksen tulee olla siihen sijoitettua panosta suurempi.

Rakennemuutosta yritetään nyt hallita toimilla, joiden pääpaıno on "uhrien hoidossa" ja toisaalta rakennemuutoksen estämisessä. Päättäjiltä tarvitaan asennemuutosta: toimenpiteiden pääpainon siirtämistä rakennemuutosta edistäviin toimiin.

Helppo keino rakennemuutoksen hallintaan on ollut kokeneiden ihmisten työntäminen sosiaaliturvan varaan. Varhaiseläkkeillä, erorahalla ja työttömyysturvalla on pyyhkäisty työmarkkinoilta 200000 työhön kykenevää ja työikästä syrjään. Sosiaaliturvajärjestelmät on muutettava passivoivista aktivoiviksi: on estettävä niiden käyttö saneerausten varaventtiileinä ja rakennettava ne koulutusta, oppimista ja työntekoa palkitseviksi.

Onnistuneen aikuiskoulutuksen tuloksena on parempi osaaminen. Yrityksille se tuo ammattitaitoista työvoimaa. Lisäksi yritys voi olla varma sekä omasta että työntekijöidensä paremmasta muutosvalmiudesta. Työntekijälle parempi osaaminen ja itsensä kouluttaminen on ainoa todellinen työelämän turva ja elintason kohentamiskeino. Myös yritysten tulisi muuttaa asenteitaan: On pakko uudelleenkouluttaa myös yrityksessä olevia. Toimivan aikuiskoulutusjärjestelmän avulla syntyvä osaaminen luo yhteiskunnalle edellytykset kilpailukyvyn parantamiseen ja hyvinvoınnın jatkuvaan kehittämiseen.

Aikuiskoulutukseen tarvittavat voimavarat ovat jo päáosin olemassa. Koulutuksen infrastruktuuri ja voımavarat on käytettävä nykyistä tehokkaammin (päätöksentekoa hajautetaan; koulurakennukset tehokäyttöön; opettajat yrityskoulutusjaksoille; tyhjät ammattikoulutuspaikat aikuisten uudelleenkoulutukseen; oppisopimuskoulutuksesta aikuiskoulutusmalli). Työntekijä voi panostaa koulutukseen omaa vapaa-aikaansa ja opiskeluun tarvittavaa energiaa. Yrityksıssä on tietoa nykyisistä ja tulevaisuuden tarpeista. Yritysten asiantuntijat voivat toimia "vierailevina" opettajina. Yrityksen voimavarat tulevat käyttöön monella muullakin tavalla. Tuskin aikuisten ammattikoulutusta on järjestettävissä ilman työajan käyttöä koulutustarkoituksiin. Olisi yhdessä vakavasti harkittava, voitaisiinko jo sovittua työajan lyhennystä käyttää ammattikoulutukseen.

Koulutusrahasto ei ole ratkaisu esillä oleviin ongelmın. Kytkennästä tulopoliittisiin neuvotteluihin on syytä varoittaa. Onnistuminen edellyttää yhteistoi- 
mıntaa yrityksissä, järjestöissä ja viranomaisten kesken ja kaikkien niiden välillä. Työmarkkinajärjestöillä on valmis yhteistyön koneisto, joka on käytettävissä. Ehdotan, että työmarkkinajärjestöt ottaisivat aikuisten ammatillisen koulutuksen jatkuvan, pitkäjännitteisen yhteistyön kohteeksi.

Koulutusta pidetään lähes poikkeuksetta hallitun rakennemuutoksen, tuottavuuden kohentamisen ja hyvinvoinnin saavuttamisen välineenä. Suoniokin pitää esityksessään kasvatusta välineenä: "Koulu voi ja sen tulee kasvattaa tulevaisuuteen". Tosin Suonio korostaa ansiokkaasti oppimisprosessien merkitystä, minkä myös Laine on ymmärtänyt olennaiseksi puhuessaan oppimisprosessien käynnistämisestä organisaatiossa. Näkemykseen, jonka mukaan oppiminen on elämää, ei konferenssissa ylletä. Pellikka painottaa tehokkuutta. Pellikan esityksessä on varteenotettavia koulutusresurssien käytön tehostamisehdotuksia. Työn ja tehokkuuden arvot kuitenkin hallitsevat ja peittävät alleen ihmisarvon ja inhimillisyyden. Pellikan lausuma koulutuksesta työmarkkinajärjestöjen turmeltumattomana yhteistyöalueena on hurskastelua, sillä hän sitoo kätensä jo esityksessään asennoitumalla torjuvasti koulutusrahastoihin.

Aikuisopintojen ja aikuiskasvatuksen näkökulmasta konferenssin pääesityksiä koulutuksesta ei voi pitää onnistuneena. Suonio tarkasteli ensisijaisesti lasten ja nuorten koulutusta ja aikuiskoulutusta vain vähäisessä määrin. Pellikan ajatusmaailma on yksipuolinen: tehokkuuden maksimointi on hänen unelmansa.

\section{Yhteisymmärryksen syventäminen}

Hallitusvaltaa pitävien keskustelua yhteisymmärryksen syventämisestä hallitsee työn arvo, ei ihmisarvo. Työksi katsotaan palkkatyö ja toiminta, jolla ansaitaan rahaa tai kartutetaan pääomaa. Muuta toimintaa ei lueta työksi. Korostetaan, että ihmisiä pitää motivoida tekemään työtä. Motivoimisesta elämään täydesti ihmisarvoista elämää ei puhuta. Ihmisen arvo ja lisäarvo rakentuvat työlle ja vauraudelle, eivät ihmisyydelle eivätkä kansalaisuudelle.

Opposition näkökulmasta voidaan asettaa kysymyksiä: Onko maan hallitus enemmän yritysten ja etujärjestöjen kuin ihmisten ja kansalaisten asialla? Eikö julkisen vallan tulisi ensisijaisesti toimia kokonaisuus halliten niiden ihmisten ja kansalaisten puolesta, joista työmarkkinaosapuolet huolehtivat huonosti tai eivät lainkaan? Eikö juuri silloin, kun tuottavuus ja vauraus ovat kasvaneet, olisi varaa hahmotella uudestaan yhteiskunnan rakentamista ihmisyyden ja kansalaisuuden varaan? Eikö täl- laisena aikana olisi tärkeää selvittää ja ratkaista, miten kansalaisten ja maahanmuuttajien toimeentulo järjestetään kokonaisvaltaisesti erillismenettelyistä (lapsilisät, sosiaalihuolto, työttömyyskorvaukset, erorahat, eläkkeet, verotus ) yksinkertaisesti yhdistäen, lainsäädäntöä pelkistäen ja tulonjakoa tasaten? Lähihistoria on jo kyllin selkeästi osoittanut, että tähän eivät työmarkkina- eivätkä muutkaan etujärjestöt kykene. Hyvinvoivien pyrkimys vointinsa kohentamiseen on rajaton. Eivät yksityksellä eivätkä julkisella sektorilla suurempia palkkoja nauttivat johtajat eivätkä työntekijät ole ilmaisseet tyytyvänsä vähempiin nettotuloihin kuin mitä he nyt ansaitsevat. Vai havahdutetaanko esim. pikkulapset tunnustamaan perustoimeentuloon oikeutetuiksi ihmisiksi vasta kun työvoimapula (lapsipula) käy sietämättömäksi?

Mikäli yhteisymmämystä halutaan puolin ja toisin laajentaa, perustavaa laatua oleva kysymys kuuluu: Kuinka pian yhteisymmärrystä on syvennettävissä siten, että hallitus - kokoonpanostaan riippumatta - on valmis keskustelemaan aiheen ihminen uudistuvassa työelämässä ohella tai sijasta aiheesta uudistuva ihminen työelämässä ja milloin vihdoin aiheesta uudistuva ihminen.

Ammatillisen koulutuksen ja vapaan sivistystyön kannattajien yhteisymmämyksen syventämisestä ei juurikaan ole puhuttu. Äänessä ovat ammatillisen koulutuksen kannattajat ja erityisesti työmarkkinajärjestöt, jotka ovat ottaneet hallintaansa aikuiskoulutuskeskustelun. Vapaan sivistystyön kannattajien ääni hukkuu myötätuuleen. Kouluhallitus ja kasvatustiede vaikenevat sosiaalisen tilauksen äärellä. Suunnitelmia puuttuu, tai jos niitä on, ne haudataan. Juuri nyt kuitenkin tarvittaisiin alalla asiantuntemusta, suvaitsevaisuutta, yhteisymmärrystä ja yhteisymmärryksen syventämistä.

Myös koulutuskeskustelun perusarvoksi asettuu työ, ei ihminen eikä kansalainen. Keskustelussa hallitusta rakennemuutoksesta koulutuksella osoitetaan välinemerkitys: koulutus on rakennemuutoksen keino, keino suunnata ihminen työalalta toiselle, työtehtävistä toisiin työtehtäviin. Koulutusta pidetään vaikuttamisen välineenä: joku tai jotkut kouluttavat, opettavat muita, vaikuttavat toisiin. Kyse on vaikuttamisesta ja vallankäytöstä. Ihmisyyden lähtökohdista tulisi oppimista painottaa koulutusta vahvemmin. Lähtökohtana olisi tällöin ihmisen oma tahto ja halu asettaa itselleen päämääriä ja tavoitteita, joita kohti hän voi pyrkiä oppimalla ja opiskelemalla.

Ihmisten vapaasta tahdosta purkautuva opiskelunhalu on ollut vapaan sivistystyön aateperustana. Järjenvastaista on, että tämän vapauden ideologian nimissä on henkeen ja ve- 
reen vastustettu vapaan sivistystyön suuntautumista palvelemaan työn ideologiaa. Vapaan sivistystyön oppilaitoksissa on vieroksuttu työhön liittyvää opetusta huolimatta siitä, että huomattava osa opiskelijoista opiskelee niissä nimenomaan parantaakseen edellytyksiä menestyä työelämässä. Vapaan sivistystyön edustajille yhteisymmärryksen syventymistä on, että Pellikkaakin pitää voida ymmärtää. On ihmisiä, joille työ on ensiarvoista ja jotka haluavat kehittyä työssään ja kehittää työtään sekä työ että vapaa-aikoinaan. On ihmisiä, jotka haluavat vaihtaa alaa ja haluavat valmistautua siihen vapaa-aikoinaan. Tällaisia henkilöitä on palkkatyössä mm. vapaan sivistystyön oppilaitoksissa ja järjestöissä. Vapaa sivistystyö voisi vapautua paradoksistaan ja kyetä laajentamaan vapausnäkemyksensä siten, että sen toimien piiriin kuuluu varauksetta myös työstä kiinnostuneiden ihmisten tukeminen. Jotta tähän voitaisiin kiertelemättä ja kaartelematta päätyä ja luoda esim. kansalaisopistoista inhimillisen kasvun ja kulttuurin tukikohtia, tarvitaan niitä koskevan lainsäädännön perusteellinen remontti. (Ks. Pentti Pitkänen: Kansalaisopistot kunnallisina oppilaitoksina, 1988). Tarvitaan avartuvaa yhteisymmärrystä, jotta esim. suurimpiin kuntiin voitaisiin perustaa opintolautakunta huolehtimaan kattavasti aikuisten sekä yleissivistävien että ammatillisten opintojen kehittämisestä.

Toisaalta työhön ja tehokkuuteen juuriaan myöten sidoksissa olevien tulisi hyväksyä se tosiasia, että on olemassa muunkinlaisia ihmisiä. On ihmisiä, jotka palvelevat muita siitäkin huolimatta, vaikka eivät saa siitä palkkaa. On ihmisiä, jotka eivät halua antautua palkkaorjiksi, mutta huolehtivat itsestään ja lähimmäisistäänkin. On ihmisiä, jotka eivät pidä työstä eivätkä halua tehdä työtä. Kaikille näillekin ihmisille pitäisi myöntää ihmisarvo ja sen nojalla perustoimeentulo. Heiltäkään ei pidä kiel- tää oikeutta oppimiseen. Avattakoon oppimisen ovet, ei vain kansalaisopistoihin, vaan myös ammatillisiin oppilaitoksiin ja korkeakouluihin niillekin, jotka eivät tähtää ammattitutkintoihin tai työelämään, vaan elämään.

Erityisesti valtiovallan ja julkisen hallinnon tulisi minimoida tiedon esteitä maailmassa, jossa tieto uhkaa sulkeutua rahasalpojen taakse. Kun koulutuksen arvo tajutaan, se kallistuu ja ajautuu markkinavoimien syliin. Tietoa voi saada vain se, jolla on rahaa. Tämä kehityssuunta on tosiasia, jolta ei ole lupa ummistaa silmiä. Sen yhtenä ilmenemänä on keskustelu koulutusrahastoista. Työnantajalta ja työntekijöiltä kerättävien rahastojen luominen edistäisi varmasti sekä yritysten että työntekijöiden kehitystä. Rahastojen käytön tulisi kuitenkin olla väljää siten, että työntekijä voi käyttää kartuttamaansa rahaa yhtä hyvin nykyistä työpaikkaa kuin työpaikan vaihdosta ja myös vapaata itsensä kehittämistä edistävään opiskeluun. Työtä tekevät voivat varsin hyvin rahastojen avulla luoda edellytyksiä kehittää itseään, osallistua koulutukseen ja harjoittaa opintoja. Julkisen hallinnon ja sen laitosten kuten esim. kansalaisopistojen tulee kuitenkin huolehtia siitä, että varattomillekin annetaan samat mahdollisuudet itsensä kehittämiseen kuin varakkaillekin ja työssä käyville. On syytä syventää yhteisymmärrystä siten, että tajutaan, ettei ihmisen ainutkertaisen ja -laatuisen elämän sitominen yhteen ja ainoaan työpaikkaan, vieläpä mahdollisesti yhteen ja samaan yksitoikkoiseen ja toisten tahdon ohjaamaan työtehtävään, voi olla elämän tarkoitus.

\section{Lähteet}

Valtioneuvoston tiedotusyksikkö, Ihminen uudistuvassa työelämässä, talouspoliittinen konferenssi 17.11.1987, Joensuu.

Pitkänen, Pertti, Kansalaisopisto kunnallisena oppilaitoksena, Vantaa, 1988. 


\section{AIKUISKASVATUS \\ The Finnish Journal of Adult Education \\ Vol. 8,1/88 \\ ISSN 0358-6197 \\ Summary}

Pitkänen, Pentti. 1988. The Human Aspect in

Working Life Reformation.

Attended by top politicians, an economicpolitical conference titled "The Human Aspect in Working Life Reformation" was held in Joensuu in November of 1987. Adult education was among the leading themes of discussion at the conference. This article is a presentation and analysis of the central political and edu-cational ideas expressed in the papers presen-ted at the conference. Almost without excep-tion, the speakers considered education as a means to, achieving the goals of the reforma-tion, improved productivity and social welfare. Education was seen as a means to directing people from one occupation to another, from one task to another. Work and the economy were seen as constituting the premises and basic values dominating people and educati-on in the views expressed by political parties and trade unions. The representatives of the opposition party were alone in placing human value to be of primary importance. 